\title{
Trypsin inhibitor and the nutritional value of soya beans
}

\author{
By S. LEPKOVSKY, F. FURUTA AND MILDRED K. DIMICK \\ Department of Poultry Husbandry, University of California, \\ Berkeley, California $94720, U S A$
}

(Received I5 May 1970-Accepted 21 September 1970)

\begin{abstract}
I. One reason, based on indirect evidence, advanced in explanation of the low nutritional value of raw soya bean (RS) is that it stimulates the pancreas to secrete massive amounts of protein which are ultimately lost in the faeces. This theory has been investigated directly.

2. The expected outpouring of pancreatic protein did not occur when the secretion of enzymes and protein in pancreatic juice from chickens and rats given successively heated soya bean (HS) and RS diets was measured directly.

3. It is suggested that RS, acting upon intestinal proteins, forms trypsin inhibitor-protein complexes which, in spite of adequate proteolytic activity, escape digestion and are lost with the faeces, thus decreasing the nutritional value of the diet.
\end{abstract}

Since the demonstration by Osborne \& Mendel (I9I7) that raw soya-bean (RS) diets are inferior to properly heated soya-bean (HS) diets, continuous investigation has sought to uncover the causes for that inferiority. In spite of the great amount of work done (see review by Mickelsen \& Yang, i 966), these causes have not been found.

The discovery of a heat-labile trypsin inhibitor in RS (Ham \& Sandstedt, I944; Bowman, I944) suggested that the low nutritional value of the RS diet used was due to impaired proteolysis (Riesen, Clandinin, Elvehjem \& Cravens, 1947), which resulted in a decreased absorption of nitrogen and methionine (Bouthilet, Hunter, Luhman, Ambrose \& Lepkovsky, 1950; Kwong, Barnes \& Fiala, 1962). Doubt was cast upon this logical interpretation when it was shown that a concentrate of the trypsin inhibitor depressed growth when it was added to diets containing predigested proteins (Klose, Greaves \& Fevold, 1948; Westfall, Bosshardt \& Barnes, r948).

A new explanation was advanced by Haines \& Lyman (I96r), who suggested that RS diets stimulated the pancreas of rats to secrete excessive amounts of proteins which were ultimately lost in the faeces. This conclusion was based upon the following evidence: (I) The enzymes of the pancreas decreased much more after a meal of the RS diet than after a meal of HS diet in both chickens (Lepkovsky, Furuta, Koike, Hasegawa, Dimick,. Krause \& Barnes, I965) and rats (Lyman \& Lepkovsky, I957). (2) The zymogen granules of the acini cells of the pancreases of chickens (Applegarth, Furuta \& Lepkovsky, 1964) and of rats (Booth, Robbins, Ribelin \& DeEds, 1960) were depleted after a meal of RS diet but not after a meal of HS diet. (3) The percentage of $\mathrm{N}$ was higher in the intestinal contents of rats (Lyman, 1957) and of chickens (Lepkovsky et al. 1965) after a meal of RS diet, again suggesting excessive secretion of protein by the pancreas.

Evidence for this theory was thus indirect. Direct evidence, obtained in the study reported here, in which proteins and enzymes were measured in pancreatic juice of chickens and rats given successively HS and RS diets, failed to support the theory. 


\section{EXPERIMENTAL}

Expt I. Experiments with chickens. White Leghorn chickens, 5-8 months old and weighing $1600-1800 \mathrm{~g}$, were used. The large pancreatic duct was fistulated by means of a $\mathrm{PE}-5 \circ$ polyethylene tube; the small and accessory ducts were left intact. The tube was exteriorized and pancreatic juice was collected continuously in suitable containers at intervals of $8 \mathrm{~h}$ to avoid loss of enzyme activity. It was found that, if the containers were allowed to remain in contact with the bodies of chickens for longer periods of time, the enzymic activity of the pancreatic juice began to decrease. The pancreatic juice was lost to the chicken. Periodically, electrolytes (Spencer, 1960) were given by tube to replace loss of pancreatic juice, but no response was observed. Consequently, electrolytes were not used routinely. Ileostomies were made before, after or at the same time as the fistulations. Intestinal contents (intestinal effluent) were collected through the ileostomy at the same time that the pancieatic juice was collected. The collected materials were frozen and freeze-dried. Dry matter, N, proteases, amylase and lipase were determined in the pancreatic juice and intestinal contents.

Expt 2. Experiments with rats. The pancreatic ducts of 4-month-old Sprague-Dawley rats, weighing approximately $300 \mathrm{~g}$, were cannulated and were used after recovery from surgery $(3-5 \mathrm{~d})$ when the animals began to eat normally and regular flow of pancreatic juice was established. Pancreatic juice was collected by the technique of Sawyer \& Lepkovsky (1935), which was developed for the collection of bile, and which made it possible to collect pancreatic juice from the rats without restraining them. The bile was diverted to the lower intestine, yielding pancreatic juice free or almost free of bile. The rats were prepared by Dr Richard L. Pencharz, and details of the method will be published elsewhere. A solution of electrolytes (Spencer, I960) was offered, in addition to the regular drinking water. No intestinal contents were collected. Collections of pancreatic juice were made every $3-4 \mathrm{~h}$ around the clock and were combined to make $24 \mathrm{~h}$ collections, which were analysed for dry matter, $\mathrm{N}$, proteases, amylase and lipase.

Feeding schedule. HS and RS diets (Lepkovsky et al. 1965) were used. The chickens were maintained on the HS diet and were changed to the RS diet for two or three $24 \mathrm{~h}$ periods. With chickens $\mathrm{C}_{2632}$ and $\mathrm{C} 2264$ collections were not made for the rst day of RS feeding.

The rats were given HS diet following surgery. After recovery, HS diet was given for $3 \mathrm{~d}$ and changed to RS diet for $3 \mathrm{~d}$, after which the rats were returned to HS diet for $3 \mathrm{~d}$.

Food was available at all times to both chickens and rats. Two aphagic chickens (C2295 and $\mathrm{C}_{21}$ 48) were force-fed. Rats that reduced their food intakes were forcefed amounts sufficient to make food intakes similar (10-12 g) between rats.

Analytical techniques. Pancreatic enzymes were determined by methods previously described (Lepkovsky, Wagner, Furuta, Ozone \& Koike, 1964).

$\mathrm{N}$ was determined by the micro-Kjeldahl method.

Samples of intestinal contents from three chickens were treated with acid to dissociate the trypsin-trypsin inhibitor complex to provide more valid values for the 
protease levels in the intestinal effluent of those chickens given RS diet. The lyophilized intestinal contents were homogenized with distilled water $(2-5 \mathrm{mg} / \mathrm{ml})$, and $\mathrm{I} \cdot 5 \mathrm{ml}$ of the homogenate were incubated with $1.5 \mathrm{ml}$ of $0.10 \mathrm{~N}-\mathrm{HCl}$ at $3^{\circ}$ for $30 \mathrm{~min}$. Portions of $0.5 \mathrm{ml}$ were then added to the buffered-haemoglobin substrate, and the proteolytic activity was determined as described by Anson (1939).

\section{RESULTS}

Of the many animals operated on, only four rats and five chickens survived long enough to permit $24 \mathrm{~h}$ collections of pancreatic juice after successive feedings of $\mathrm{HS}$ and RS diets. One of the most common difficulties encountered was the cessation of the flow of pancreatic juice due to the plugging of the tubes. Heatley, McElheny \& Lepkovsky (1965) described this difficulty in chickens.

Expt $\mathrm{x}$. Results with chickens. Fistulation of the large pancreatic duct markedly influenced food intake in two chickens which became aphagic and in one which became hyperphagic; two ate normally. The percentage of $\mathrm{N}$ in the intestinal contents was higher in chickens given RS diet than in those given HS diet, in agreement with previous results obtained with intact chickens (Lepkovsky et al. 1965). The $N$ of the intestinal contents calculated per $\mathrm{g}$ food intake was greater in chickens given RS than in those given HS diet. The amount of $\mathrm{N}$ absorbed from the intestine as a percentage of the $\mathrm{N}$ intake of the chickens given RS diet was less than that of chickens given HS diet (Table I), and also agreed with results obtained with intact chickens (Lepkovsky et al. 1965$)$.

Table I. Food intake, nitrogen content of pancreatic juice and of intestinal contents collected at the same time, and percentage of food $N$ absorbed, in chickens given successively heated $(H S)$ and raw $(R S)$ soya-bean diets

\begin{tabular}{|c|c|c|c|c|c|c|c|c|c|c|}
\hline \multirow[b]{2}{*}{$\begin{array}{l}\text { Chicken } \\
\text { no. }\end{array}$} & \multirow[b]{2}{*}{$\begin{array}{l}\text { Time } \\
\text { after } \\
\text { surgery } \\
\text { (d) }\end{array}$} & \multirow[b]{2}{*}{ Diet } & \multirow[b]{2}{*}{$\begin{array}{l}\text { Mean } \\
\text { food } \\
\text { intake } \\
(\mathrm{g} / \mathrm{d})\end{array}$} & \multirow[b]{2}{*}{$\begin{array}{c}N \\
\text { intake } \\
(\mathrm{g} / \mathrm{d})\end{array}$} & \multicolumn{3}{|c|}{$\mathrm{N}$ in intestinal contents } & \multicolumn{3}{|c|}{$\mathrm{N}$ in pancreatic juice* } \\
\hline & & & & & $\begin{array}{l}\% \text { dry } \\
\text { matter }\end{array}$ & $\begin{array}{l}\mathrm{mg} / \mathrm{g} \\
\text { food } \\
\text { intake }\end{array}$ & $\begin{array}{c}\text { Absorbed } \\
\text { (as \% } \\
\text { intake) }\end{array}$ & $\%$ & $\begin{array}{l}\text { Total } \\
(\mathrm{mg})\end{array}$ & $\begin{array}{c}\text { As } \% \mathrm{~N} \text { in } \\
\text { intestinal } \\
\text { contents }\end{array}$ \\
\hline $\mathrm{C}_{2} 632$ 孚 & $\begin{array}{l}18,19 \\
21,22\end{array}$ & $\begin{array}{l}\text { HS } \\
\text { RS }\end{array}$ & $\begin{array}{r}108 \\
62\end{array}$ & $\begin{array}{l}3 \cdot 74 \\
2 \cdot 17\end{array}$ & $\begin{array}{l}3 \cdot 1 \\
5 \cdot 0\end{array}$ & $\begin{array}{r}9.07 \\
14.84\end{array}$ & $\begin{array}{l}73 \cdot 8 \\
57 \cdot 6\end{array}$ & $\begin{array}{l}12 \cdot 4 \\
11 \cdot 4\end{array}$ & $\begin{array}{r}140 \\
60\end{array}$ & $\begin{array}{r}r 4.3 \\
6.5\end{array}$ \\
\hline $\mathrm{Cr}_{42 \mathrm{I}}$ ? & $\begin{array}{l}42,43 \\
44,45\end{array}$ & $\begin{array}{l}\text { HS } \\
\text { RS }\end{array}$ & $\begin{array}{l}94 \\
46\end{array}$ & $\begin{array}{l}3.25 \\
1.61\end{array}$ & $\begin{array}{l}3 \cdot 3 \\
4 \cdot I\end{array}$ & $\begin{array}{r}8.09 \\
18.04\end{array}$ & $\begin{array}{l}76 \cdot 6 \\
48 \cdot 4\end{array}$ & $\begin{array}{r}10.8 \\
9.8\end{array}$ & $\begin{array}{r}5^{\circ} \\
5\end{array}$ & $\begin{array}{l}6.6 \\
0.6\end{array}$ \\
\hline $\mathrm{C}_{2148}+$ & $\begin{array}{r}8,9 \\
\text { I0, I I }\end{array}$ & $\begin{array}{l}\text { HS } \\
\text { RS }\end{array}$ & $\begin{array}{l}34 \dagger \\
38 \dagger\end{array}$ & $\begin{array}{l}\mathrm{I} \cdot \mathrm{I} 8 \\
\mathrm{I} \cdot 3 \mathrm{I}\end{array}$ & $\begin{array}{l}3.4 \\
4 \cdot 5\end{array}$ & $\begin{array}{l}11 \cdot 76 \\
14 \cdot 53\end{array}$ & $\begin{array}{l}66 \cdot 0 \\
58 \cdot 5\end{array}$ & $\begin{array}{l}\text { II } I \cdot I \\
I I \cdot I\end{array}$ & $\begin{array}{l}96 \\
89\end{array}$ & $\begin{array}{l}24 \cdot 0 \\
16 \cdot 3\end{array}$ \\
\hline $\mathrm{C}_{22640} 0^{*}$ & $\begin{array}{l}6,7 \\
9, \text { I0 }\end{array}$ & $\begin{array}{l}\text { HS } \\
\text { RS }\end{array}$ & $\begin{array}{l}132 \\
185\end{array}$ & $\begin{array}{l}4 \cdot 57 \\
6 \cdot 48\end{array}$ & $\begin{array}{l}2 \cdot 6 \\
5 \cdot I\end{array}$ & $\begin{array}{r}5 \cdot 73 \\
11 \cdot 37\end{array}$ & $\begin{array}{l}83 \cdot 4 \\
67 \cdot 6\end{array}$ & $\begin{array}{l}7.0 \\
8.8\end{array}$ & $\begin{array}{l}28 \\
53\end{array}$ & $\begin{array}{l}3.7 \\
2.5\end{array}$ \\
\hline
\end{tabular}

The $\mathrm{N}$ in $24 \mathrm{~h}$ collections of pancreatic juice varied widely among the chickens; less $\mathrm{N}$ was secreted in two chickens when they were given RS than when they were given HS diet; approximately equal amounts were present in the pancreatic juice of one chicken with both diets, and more was secreted in the pancreatic juice of the fourth chicken when it was given RS than when it was given HS diet (Table I).

Enzymes in pancreatic juice fluctuated widely and to some extent were correlated 
with food intake (Table 2). The amounts of proteases, amylase and lipase were smaller in the pancreatic juice of two chickens when they were given RS than when they were given HS diet; no difference was found in one chicken, and in two chickens the amounts were greater when they were given RS diet.

With one exception, the amount of proteases was greater in the intestinal contents of the chickens given HS diet than in those given RS diet, but lipase and amylase activities were lower in the intestinal contents of the chickens given HS diet.

Expt 2. Results with rats. Tables 3 and 4 show the results obtained with rats with

Table 2. Total pancreatic enzyme activities in intestinal contents receiving pancreatic juice from intact small and accessory pancreatic ducts, and in pancreatic juice from the fistulated large duct of chickens given successively heated $(H S)$ and raw $(R S)$ soya-bean diets

\begin{tabular}{|c|c|c|c|c|c|c|c|c|c|c|c|}
\hline \multirow[b]{3}{*}{$\begin{array}{c}\text { Chicken } \\
\text { no. }\end{array}$} & \multicolumn{11}{|c|}{ Protease activity* } \\
\hline & \multirow[b]{2}{*}{$\begin{array}{c}\text { Time } \\
\text { after } \\
\text { surgery } \\
\text { (d) }\end{array}$} & \multirow[b]{2}{*}{ Diet } & \multirow[b]{2}{*}{$\begin{array}{l}\text { Mean } \\
\text { food } \\
\text { intake } \\
(\mathrm{g} / \mathrm{d})\end{array}$} & \multirow[b]{2}{*}{$\begin{array}{c}N \\
\text { intake } \\
(\mathrm{g} / \mathrm{d})\end{array}$} & \multicolumn{2}{|c|}{$\begin{array}{l}\text { Intestinal } \\
\text { contents }\end{array}$} & \multirow[b]{2}{*}{$\begin{array}{l}\text { Pan- } \\
\text { creatic } \\
\text { juice }\end{array}$} & \multicolumn{2}{|c|}{ Amylase activity $\dagger$} & \multicolumn{2}{|c|}{ Lipase activity $\rfloor$} \\
\hline & & & & & $\begin{array}{c}\text { No } \\
\text { treat- } \\
\text { ment }\end{array}$ & $\begin{array}{c}\text { Acid } \\
\text { treat- } \\
\text { ment }\end{array}$ & & $\begin{array}{c}\text { Intes- } \\
\text { tinal } \\
\text { contents }\end{array}$ & $\begin{array}{l}\text { Pan- } \\
\text { creatic } \\
\text { juice }\end{array}$ & $\begin{array}{c}\text { Intes- } \\
\text { tinal } \\
\text { contents }\end{array}$ & $\begin{array}{l}\text { Pan- } \\
\text { creatic } \\
\text { juice }\end{array}$ \\
\hline $\mathrm{C}_{2632}$ 우 & $\begin{array}{l}18,19 \\
21,22\end{array}$ & $\begin{array}{l}\text { HS } \\
\text { RS }\end{array}$ & $\begin{array}{r}108 \\
62\end{array}$ & $\begin{array}{l}3 \cdot 74 \\
2 \cdot 17\end{array}$ & $\begin{array}{r}12 \cdot 3 \\
3 \cdot 5\end{array}$ & $\begin{array}{r}10.9 \\
6.8\end{array}$ & $\begin{array}{l}35.6 \\
16.4\end{array}$ & $\begin{array}{l}198 \cdot 8 \\
477 \cdot 9\end{array}$ & $\begin{array}{l}4920 \\
1972\end{array}$ & $\begin{array}{r}24 \cdot I \\
239^{\circ} 0\end{array}$ & $\begin{array}{r}175.5 \\
84.7\end{array}$ \\
\hline $\mathrm{C}_{1421}$ ㅇ & $\begin{array}{l}42,43 \\
44,45\end{array}$ & $\begin{array}{l}\text { HS } \\
\text { RS }\end{array}$ & $\begin{array}{l}94 \\
46\end{array}$ & $\begin{array}{l}3.25 \\
1.61\end{array}$ & $\begin{array}{l}3 \cdot 04 \\
1 \cdot 04\end{array}$ & $\begin{array}{l}3.04 \\
1.47\end{array}$ & $\begin{array}{l}8 \cdot 9 x \\
0.76\end{array}$ & $\begin{array}{l}123.4 \\
329 \cdot 0\end{array}$ & $\begin{array}{r}1430 \\
137\end{array}$ & $\begin{array}{l}14.7 \\
69.9\end{array}$ & $\begin{array}{r}24.5 \\
3.4\end{array}$ \\
\hline $\mathrm{C}_{2295}$ 우 & $\begin{array}{l}21,22 \\
23,24\end{array}$ & $\begin{array}{l}\text { HS } \\
\text { RS }\end{array}$ & $\begin{array}{l}51 \S \\
73 \S\end{array}$ & $\begin{array}{l}1 \cdot 77 \\
2 \cdot 56\end{array}$ & $\begin{array}{l}2 \cdot 57 \\
2 \cdot 60\end{array}$ & $\begin{array}{l}2 \cdot 36 \\
3 \cdot 96\end{array}$ & $\begin{array}{l}4 \cdot 13 \\
4 \cdot 34\end{array}$ & $\begin{array}{r}169 \cdot 0 \\
1331 \cdot 0\end{array}$ & $\begin{array}{l}489 \\
53^{\circ}\end{array}$ & $\begin{array}{r}1 \cdot 04 \\
13.72\end{array}$ & $\begin{array}{l}2 \cdot 8 \\
2 \cdot 7\end{array}$ \\
\hline $\mathrm{C}_{2148}$ 우 & $\begin{array}{r}8,9 \\
\text { I0, II }\end{array}$ & $\begin{array}{l}\text { HS } \\
\text { RS }\end{array}$ & $\begin{array}{l}34 \$ \\
38 \S\end{array}$ & $\begin{array}{l}I \cdot I 8 \\
I \cdot 3 I\end{array}$ & $\begin{array}{l}5.81 \\
0.65\end{array}$ & - & $\begin{array}{l}13.46 \\
18.87\end{array}$ & $\begin{array}{r}66 \cdot 2 \\
189 \cdot 1\end{array}$ & $\begin{array}{l}3024 \\
2463\end{array}$ & - & - \\
\hline $\mathrm{C}_{2264}{ }^{*}$ & $\begin{array}{l}6,7 \\
9, \text { I0 }\end{array}$ & $\begin{array}{l}\text { HS } \\
\text { RS }\end{array}$ & $\begin{array}{l}\text { I32 } \\
\text { I85 }\end{array}$ & $\begin{array}{l}4 \cdot 57 \\
6 \cdot 48\end{array}$ & $\begin{array}{r}13.61 \\
7.46\end{array}$ & - & $\begin{array}{r}8 \cdot 59 \\
21 \cdot 69\end{array}$ & $\begin{array}{l}\text { I } 19 \cdot 4 \\
985 \cdot 3\end{array}$ & $\begin{array}{r}639 \\
1050\end{array}$ & $\begin{array}{r}3.63 \\
13.74\end{array}$ & $\begin{array}{r}3 \cdot 8 \\
11 \cdot 0\end{array}$ \\
\hline
\end{tabular}

Table 3. Dry matter and nitrogen content in $24 h$ collections of pancreatic juice from fistulated pancreatic ducts of four rats $(\mathrm{I}-4)$ given successively heated $(H S)$ and raw $(R S)$ soya-bean diets

\begin{tabular}{|c|c|c|c|c|c|c|c|c|c|c|c|c|c|}
\hline \multirow[b]{3}{*}{ Diet } & \multirow[b]{3}{*}{ Day } & \multirow{2}{*}{\multicolumn{4}{|c|}{$\begin{array}{c}\text { Dry matter } \\
\text { (g) }\end{array}$}} & \multicolumn{8}{|c|}{$\mathrm{N}$ content } \\
\hline & & & & & & & & & & & Total & $\mathrm{mg})$ & \\
\hline & & I & 2 & 3 & 4 & I & 2 & 3 & 4 & I & 2 & 3 & 4 \\
\hline HS & $\begin{array}{l}1 \\
2 \\
3\end{array}$ & $\begin{array}{c}0.367 \\
0.457 \\
-\end{array}$ & $\begin{array}{l}0.172 \\
0.128 \\
0.243\end{array}$ & $\begin{array}{l}0.333 \\
0.365 \\
0.246\end{array}$ & $\begin{array}{c}0.177 \\
0.236 \\
-\end{array}$ & $\overline{-}$ & $\begin{array}{l}7 \cdot 59 \\
7 \cdot 74 \\
8 \cdot 19\end{array}$ & $\begin{array}{l}\text { IO } 69 \\
\text { II. I I } \\
\text { IO. } 34\end{array}$ & $\begin{array}{r}4.85 \\
5.52 \\
-\end{array}$ & - & $\begin{array}{r}\text { I } 3 . \text { I } \\
9.9 \\
\text { I9.9 }\end{array}$ & $\begin{array}{l}35 \cdot 6 \\
40 \cdot 6 \\
25 \cdot 4\end{array}$ & $\begin{array}{r}8.6 \\
13.0 \\
\end{array}$ \\
\hline $\mathrm{RS}$ & $\begin{array}{l}4 \\
5 \\
6\end{array}$ & $\begin{array}{l}0.392 \\
0.507 \\
0.437\end{array}$ & $\begin{array}{c}0.274 \\
0.232 \\
-\end{array}$ & $\begin{array}{l}0.481 \\
0.361 \\
-\end{array}$ & $\begin{array}{l}0.384 \\
0.309 \\
0.185\end{array}$ & - & $\begin{array}{l}7 \cdot 37 \\
7 \cdot 53 \\
-\end{array}$ & $\begin{array}{r}10.94 \\
9.6 \mathrm{I} \\
-\end{array}$ & $\begin{array}{l}6.62 \\
7 \cdot 28 \\
8 \cdot 45\end{array}$ & - & $\begin{array}{c}20.2 \\
17.5 \\
-\end{array}$ & $\begin{array}{c}52 \cdot 6 \\
34^{\circ} 7 \\
-\end{array}$ & $\begin{array}{l}25.4 \\
22.5 \\
15.6\end{array}$ \\
\hline HS & $\begin{array}{l}7 \\
8 \\
9\end{array}$ & $\begin{array}{c}0.419 \\
0.497 \\
-\end{array}$ & $\begin{array}{l}0.101 \\
0.234 \\
0.201\end{array}$ & $\begin{array}{l}0.159 \\
0.469 \\
0.597\end{array}$ & $\begin{array}{c}0.202 \\
- \\
-\end{array}$ & - & $\begin{array}{l}7 \cdot 94 \\
7 \cdot 22 \\
7 \cdot 77\end{array}$ & $\begin{array}{l}7 \cdot 36 \\
8 \cdot 28 \\
9 \cdot 96\end{array}$ & $\begin{array}{c}8.09 \\
-\end{array}$ & $\underline{-}$ & $\begin{array}{r}8.0 \\
\text { I } 6.9 \\
\text { I } 5.6\end{array}$ & $\begin{array}{l}\text { II.7 } \\
38 \cdot 8 \\
59 \cdot 5\end{array}$ & $\begin{array}{c}\text { 16.3 } \\
-\end{array}$ \\
\hline
\end{tabular}


fistulated pancreatic ducts. There was little difference in the amounts of dry matter, $\mathrm{N}$ and enzymes in the pancreatic juice secreted by rats successively given HS and RS diets.

Decreases in food intake were not due to loss of electrolytes with the pancreatic juice, since rats, offered a choice between water and solutions of electrolytes simulating those in pancreatic juice, consumed variable amounts of electrolytes.

Table 4. Total activity of pancreatic enzymes in $24 h$ collections of pancreatic juice from fistulated pancreatic ducts of four rats $(\mathrm{I}-4)$ given successively heated $(H S)$ and raw $(R S)$ soya-bean diets

\begin{tabular}{|c|c|c|c|c|c|c|c|c|c|c|c|c|c|}
\hline \multirow[b]{2}{*}{ Diet } & \multirow[b]{2}{*}{ Day } & \multicolumn{4}{|c|}{ Proteases* } & \multicolumn{4}{|c|}{ Amylase $\dagger$} & \multicolumn{4}{|c|}{ Lipasef } \\
\hline & & I & 2 & 3 & 4 & I & 2 & 3 & 4 & I & 2 & 3 & 4 \\
\hline HS & $\begin{array}{l}1 \\
2 \\
3\end{array}$ & $\begin{array}{c}3.77 \\
4.78 \\
-\end{array}$ & $\begin{array}{l}3.79 \\
3.07 \\
5.79\end{array}$ & $\begin{array}{r}\text { I2.33 } \\
\text { 13.45 } \\
6.79\end{array}$ & $\begin{array}{c}1 \cdot 33 \\
3 \cdot 10 \\
-\end{array}$ & $\begin{array}{l}428 \\
432 \\
-\end{array}$ & $\begin{array}{r}125 \\
69 \\
176\end{array}$ & $\begin{array}{l}623 \\
539 \\
428\end{array}$ & $\begin{array}{l}63 \\
35 \\
\end{array}$ & $\begin{array}{l}38 \\
58 \\
\end{array}$ & $\begin{array}{l}3 \mathrm{I} \\
30 \\
8 \mathrm{I}\end{array}$ & $\begin{array}{r}123 \\
130 \\
64\end{array}$ & $\begin{array}{r}7 \\
27 \\
\end{array}$ \\
\hline RS & $\begin{array}{l}4 \\
5 \\
6\end{array}$ & $\begin{array}{l}3.36 \\
3.49 \\
3.02\end{array}$ & $\begin{array}{c}5 \cdot 13 \\
4.57 \\
-\end{array}$ & $\begin{array}{c}20.40 \\
12.78 \\
-\end{array}$ & $\begin{array}{l}6 \cdot 20 \\
5.05 \\
3.49\end{array}$ & $\begin{array}{r}\text { I } 57 \\
\text { I I } 3 \\
87\end{array}$ & $\begin{array}{r}\text { I } 19 \\
94 \\
-\end{array}$ & $\begin{array}{c}732 \\
325 \\
-\end{array}$ & $\begin{array}{l}74 \\
86 \\
67\end{array}$ & $\begin{array}{l}34 \\
24 \\
80\end{array}$ & $\begin{array}{l}65 \\
50 \\
\end{array}$ & $\begin{array}{r}\text { I } 43 \\
99 \\
-\end{array}$ & $\begin{array}{l}84 \\
71 \\
44\end{array}$ \\
\hline HS & $\begin{array}{l}7 \\
8 \\
9\end{array}$ & $\begin{array}{l}2.48 \\
3.42 \\
-\end{array}$ & $\begin{array}{l}0.97 \\
2.25 \\
2 \cdot 26\end{array}$ & $\begin{array}{r}\mathbf{I} \cdot 94 \\
7.73 \\
\mathrm{I} 4.93\end{array}$ & $\frac{3.46}{-}$ & $\begin{array}{l}75 \\
94 \\
\end{array}$ & $\begin{array}{r}32 \\
95 \\
\text { I I }\end{array}$ & $\begin{array}{r}85 \\
408 \\
580\end{array}$ & $\frac{5^{I}}{-}$ & $\begin{array}{l}74 \\
48 \\
-\end{array}$ & $\begin{array}{r}5 \\
8 \\
10\end{array}$ & $\begin{array}{r}10 \\
50 \\
128\end{array}$ & $\underline{8}$ \\
\hline
\end{tabular}

\section{DISCUSSION}

In the present work, direct evidence in the form of $24 \mathrm{~h}$ collections of pancreatic juice from chickens and rats given successively HS and RS diets does not support the conclusion of Haines \& Lyman (1961), based on indirect evidence, that growth depression produced by RS diets was due, in part, to 'the effects of trypsin inhibitor, which acts, not by inhibiting protein hydrolysis, but by stimulating the pancreas to secrete large quantities of enzyme protein which are ultimately lost to the animal'. Nor do $16 \mathrm{~h}$ collections of pancreatic juice from chickens given HS and RS diets (Dal Borgo, Salman, Pubols \& McGinnis, 1968) support the conclusions based upon indirect evidence. Our work suggests that RS diets have a lower nutritional value than HS diets because RS trypsin inhibitors impair proteolysis, not by decreasing the activities of proteases in the intestinal contents but rather by their action on intestinal proteins, causing the formation of trypsin inhibitor-protein complexes which resist proteolysis even in the presence of high concentrations of proteases, and which are lost with the faeces. It is further postulated that trypsin inhibitors included in diets containing hydrolysed proteins still depress growth because they combine with endogenous intestinal proteins to form resistant complexes. This explanation has been overlooked because of the failure to appreciate the comparatively large amounts of non-pancreatic endogenous $\mathrm{N}$ that enter the intestine of the chicken (Pisano, Paine \& Taylor, 1959; Bolton, 1961), dog (Nasset, 1965) and man (Murlin, Nasset \& Marsh, 1938). 
Indirect evidence carries with it many pitfalls. Levels of enzymes in the pancreas after eating represent, at any given time, the algebraic sum of the enzymes secreted and those that are newly synthesized. Levels of $\mathrm{N}$ in the intestinal contents are equally difficult to interpret since they are influenced by the amount of endogenous $\mathrm{N}$ (intestinal juice) that enters the intestine and the rapidity with which it is absorbed (Bolton, 1961; Pisano et al. 1959). Consideration must also be given to the different amounts of food that are eaten and the rate of entry of gastric chyme into the duodenum; for example, gastric emptying is slower in chickens given RS diet than in those given HS diet (de Muelenaere, 1964). Consequently, the intestinal chymes of the HS and RS diets do not travel through the intestine at the same rate, and the composition of the intestinal contents of animals given HS or RS diet are not similar at any specific time.

Interpretation of enzyme activities in intestinal contents is even more difficult; trypsin inhibitor partly inactivates proteases, which in general are stable in the intestinal contents. Amylase, in contrast, is unstable in the intestinal contents of chickens given HS diet but is more stable in those given RS diet (Lepkovsky, Koike, Sugiura, Dimick \& Furuta, I966). Lipase is present in intestinal juice (Lepkovsky \& Furuta, 1970), but the factors that govern its secretion into the intestine are unknown.

Under certain conditions, reduction in food intake may also play a part in reducing the value of the RS diet (Osborne \& Mendel, 1917). This occurs in young animals but not in those conditioned to the RS diet. Bornstein \& Lipstein ( 1963 ) showed that the RS diet no longer decreased food intake in chickens after they had subsisted on it for 12 weeks or longer. Lepkovsky et al. (1965) observed that many chickens conditioned to the RS diet consumed larger quantities of it than did similar chickens given the HS diet. In such animals, food intake ceases to be a determinant in the nutritional value of the RS diet.

This investigation was supported in part by USPHS research grants A-I 804 and NB-7585 from the National Institutes of Health, and GB-242 and GB-6 578 from the National Science Foundation. The authors wish to thank Mr Rick Kueneman for very valuable surgical assistance in preparing the animals.

\section{REFERENCES}

Anson, M. L. (1939). F. gen. Physiol. 22, 79.

Applegarth, A., Furuta, F. \& Lepkovsky, S. (1964). Poult. Sci. 43, 733.

Bolton, W. (I96I). Proc. Nutr. Soc. 20, xxv.

Booth, A. N., Robbins, D. J., Ribelin, W. E. \& DeEds, F. (1960). Proc. Soc. exp. Biol. Med. ro4, 681.

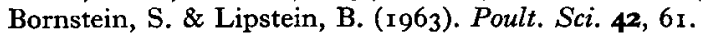

Bouthilet, R. J., Hunter, W. L., Luhman, C. A., Ambrose, D. \& Lepkovsky, S. (1950). Poult. Sci. $29,837$. Bowman, D. E. (1944). Proc. Soc. exp. Biol. Med. 57, 139.

Dal Borgo, G., Salman, A. J., Pubols, M. H. \& McGinnis, J. (1968). Proc. Soc. exp. Biol. Med. 129, 877. de Muelenaere, H. J. H. (1964). F. Nutr. 82, I 97.

Haines, P. C. \& Lyman, R. L. (I96I). F. Nutr. 74, 445.

Ham, W. E. \& Sandstedt, R. M. (I944). F. biol. Chem. 154, 505.

Heatley, N. G., McElheny, F. \& Lepkovsky, S. (1965). Comp. Biochem. Physiol. 16, 29.

Klose, A. A., Greaves, J. D. \& Fevold, H. L. (1948). Science, N.Y. 108, 88.

Kwong, E., Barnes, R. H. \& Fiala, G. (1962). F. Nutr. 77, 3 12.

Lepkovsky, S. \& Furuta, F. (r970). Poult. Sci. 49, r92. 
Vol. 25

Lepkovsky, S., Furuta, F., Koike, T., Hasegawa, N., Dimick, M. K., Krause, K. \& Barnes, F. J. (1965). Br. F. Nutr. 19, 4I.

Lepkovsky, S., Koike, T., Sugiura, M., Dimick, M. K. \& Furuta, F. (1966). Br. F. Nutr. 20, 42 I.

Lepkovsky, S., Wagner, M., Furuta, F., Ozone, K. \& Koike, T. (1964). Poult. Sci. 43, 722.

Lyman, R. L. (1957). J. Nutr. 62, 285.

Lyman, R. L. \& Lepkovsky, S. (1957). J. Nutr. 62, 269.

Mickelsen, O. \& Yang, M. G. (1966). Fedn Proc. Fedn Am. Socs exp. Biol. 25, 104.

Murlin, J. R., Nasset, E. S. \& Marsh, M. E. (1938). F. Nutr. 16, 249.

Nasset, E. S. (1965). Fedn Proc. Fedn Am. Socs exp. Biol. $24,953$.

Osborne, 'T. B. \& Mendel, L. B. (1917). Y. biol. Chem. 32, 369.

Pisano, J. J., Paine, C. M. \& 'Taylor, M. W. (1959). F. Nutr. 67, 2 I 3.

Riesen, W. H., Clandinin, D. R., Elvehjem, C. A. \& Cravens, W. W. (1947). F. biol. Chem. 167, 143.

Sawyer, L. \& Lepkovsky, S. (1935). Y. Lab. clin. Med. 20, $95^{8}$.

Spencer, R. P. (1960). The Intestinal Tract Ch. 10, p. 176. Springfield, Ill.: Charles C. Thomas.

Westfall, R. J., Bosshardt, D. K. \& Barnes, R. H. (1948). Proc. Soc. exp. Biol. Med. 68, 498. 